\title{
Correction to: Vaginal treatment with lactic acid gel delays relapses in recurrent urinary tract infections: results from an open, multicentre observational study
}

\author{
Ruth Diebold ${ }^{1}\left[\right.$ (D) $\cdot$ Bettina Schopf ${ }^{2} \cdot$ Holger Stammer $^{2} \cdot$ Werner Mendling $^{3}$
}

(c) The Author(s) 2021

\section{Correction to: Archives of Gynecology and Obstetrics https://doi.org/10.1007/s00404-021-06040-8}

In the original article published the conflicts of interest were not used in the same wording as in the manuscript submitted. The correct statement is given below:

Author R Diebold is an employee of DR. KADE Pharmazeutische Fabrik GmbH, Berlin, Germany and received support in form of salary. The authors B Schopf and H Stammer are employees of the Clinical Research Organistation Pharmalog Institut für klinische Forschung $\mathrm{GmbH}$, which was contracted by DR. KADE. The scientific study coordinator W Mendling received honorarium for this work as well as speaker honoraria at scientific training events organized by the funder.

The original article can be found online at https://doi.org/10.1007/ s00404-021-06040-8.

\footnotetext{
Ruth Diebold

ruth.diebold@kade.de

1 Dr. Kade Pharmazeutische Fabrik GmbH, Berlin, Germany

2 Pharmalog Institut für klinische Forschung GmbH, Ismaning, Germany
}

3 German Centre for Infections in Obstetrics and Gynecology, Wuppertal, Germany
Open Access This article is licensed under a Creative Commons Attribution 4.0 International License, which permits use, sharing, adaptation, distribution and reproduction in any medium or format, as long as you give appropriate credit to the original author(s) and the source, provide a link to the Creative Commons licence, and indicate if changes were made. The images or other third party material in this article are included in the article's Creative Commons licence, unless indicated otherwise in a credit line to the material. If material is not included in the article's Creative Commons licence and your intended use is not permitted by statutory regulation or exceeds the permitted use, you will need to obtain permission directly from the copyright holder. To view a copy of this licence, visit http://creativecommons.org/licenses/by/4.0/.

Publisher's Note Springer Nature remains neutral with regard to jurisdictional claims in published maps and institutional affiliations. 